\title{
Archive Buildings in the Czech Republic After 1990: the "Czech Archival Wonder" and the Present Situation
}

\section{Marie RYANTOVÁ, Doc. PH.D.}

The Institute of Archival Science and Auxiliary Historical Sciences of the Faculty of Arts at the South Bohemian University in České Budějovice

e-mail: ryantova@ff.jcu.cz

Archive Buildings in the Czech Republic After 1990: the "Czech Archival Wonder" and the Present Situation

\section{ABSTRACT}

The paper is concentrated on the explanation of the situation in the Czech Republic, what changed fundamentally after 1990: while before that the archives were situated mostly in the unsuitables old buildings, thereafter, in the period of 10-15 years, many of them were newly adapted (and alternatively supplemented by new depositories) and above all many absolutely new archive purpose-built buildings were constructed. Above all the state archives have got so much better conditions for their activities. Probably nothing like that was be achieved in such short period in the other country. Nowadays, after almost twenty years, the new archive buildings often have to respond to new requirements, or to deal with the question of the upkeep.

Edilizia archivistica nella Repubblica Ceca dopo il 1990: la "meraviglia archivistica ceca" e la situazione attuale

\section{SINTESI}

L'articolo si concentra sulla spiegazione della situazione nella Repubblica Ceca, che è cambiata fondamentalmente dopo 1990: mentre prima che gli archivi erano situati principalmente in vecchi inadatti edifici, da allora in poi, nel periodo di 10-15 anni, molti di loro sono stati recentemente adattati (ed in alternativa integrati da nuovi depositi) e soprattutto sono stati costruiti molti edifici archivistici assolutamente nuovi appositamente costruiti. Soprattutto gli archivi di Stato hanno avuto condizioni molto migliori per le loro attività. Probabilmente nulla di simile è stato realizzato in così breve periodo in un altro Paese. Oggi, dopo quasi vent'anni, i nuovi edifici di archivio debbono spesso corrispondere ai nuovi requisiti, o affrontare la questione del mantenimento.

Arhivske zgradbe v Češki republiki po letu 1990: Češko arhivsko čudo danes

\section{IZVLEC CKK}

Prispevek se osredotoča na predstavitev stanja v Češki republiki, ki se je drastično spremenilo po letu 1990: medtem ko so se prej arhivi nahajali v pretežno neprimernih starih zgradbah, so v dobi 10-15 let te zgradbe večinoma obnovili (ter jih ponekod tudi opremili z novimi skladišči), poleg tega pa je bilo namensko zgrajenih več popolnoma novih zgradb za arhivske namene. Državni arhivi imajo tako zelo boljše pogoje za svoje delo. Verjetno se v tako kratkem času v nobeni drugi državi ni doseglo nič podobnega. Danes, po skoraj dvajsetih letih, nove arhivske zgradbe morajo ustrezati tudi novim zahtevam, oziroma se ukvarjati z vprašanji vzdrževanja.

Archivní budovy po roce 1990: „český archivní zázrak“ a současná situace

\section{ABSTRAKT}

Příspěvek se zaměruje na objasnění situace v České republice, která se zásadně změnila po roce 1990: zatímco předtím se archivy nacházely většinou v nevyhovujících starých budovách, poté byla během 10 až 15 let řada z nich nově adaptována (a př́ípadně doplněna novými depozitáři) a zejména byly postaveny zcela nové archivní účelové budovy. Především státní archivy tak získaly mnohem lepší podmínky pro svou činnost. V tak krátkém období nebylo podobného výsledku dosaženo snad v žádné jiné zemi. V současné době, téměř po dvaceti letech, mnohdy i tyto nové archivní budovy musí reagovat na nové požadavky, př́ípadně se vyrovnávat s otázkou údržby. 
As we know, the word "archives" refers not only to sets of documents of permanent value intended for long-term preservation but also to the premises that make this preservation possible, ranging from various chests and cupboards, through rooms, as far as entire buildings. Whereas in the past only sets of documents from the most important or most comprehensive institutions (royal archives, public and local administrative authorities, possibly materials from ecclesiastical institutions or aristocratic families) were allocated individual buildings (or at least parts of them), in the modern age it is more usual for archive buildings to hold materials from various originators. Such archives were frequently created by adding to existing archives located in ecclesiastical or aristocratic seats, or in official buildings where the premises were in many respects quite inconvenient, unsuitable both for archive materials and for archivists. This was probably why people started thinking about archives as dark, dusty and musty rooms, crammed not only with "old papers" but also with cobwebs and possibly mice, and inhabited by an elderly, somewhat eccentric grey-haired man wearing thick glasses... Ideas about modern, well-lit buildings built to suit specific needs and requirements were implemented only gradually. It was much the same in the Czech Lands, where the first purpose-built archival building was put up between 1929 and 1933 for The Archive of the Land of Bohemia (today the building of the First Department of the National Archives) ${ }^{1}$. For a long time this building remained the only one of its kind. In the 1950s it briefly housed the Archive of the National Museum and became in particular part of the State Central - today National - Archives; today it also serves as the headquarters of the Archives Administration and Filing Service Department of the Ministry of the Interior of the Czech Republic, the supreme authority of Czech archival science, to which the state archives are directly subordinate. Other archives can be found in local administration offices, courts, chateaux, former church buildings (sometimes in the former churches themselves, and especially the monasteries that were abolished under Communism), depositories as well as in the premises of former parish offices, schools, synagogues, and in factory buildings, prisons and army barracks, etc. It was not unusual for archival material to be scattered around many buildings situated quite a long way from each other, for the most part old buildings in bad technical condition and not fulfilling even the most basic requirements, many suffering from damp, and some depositories even without an electricity supply. For example, the former Central State Archives had workplaces and depositories in fourteen places in Prague and another ten localities throughout the Czech Republic. Among them were, for example, the basement of the Ministry of Agriculture, Břevnov Monastery, the crypt under the Church of St. Nicholas in the Lesser Town in Prague, a granary in Ruzyně (not far from today's Václav Havel Airport), Broumov Monastery, a chateau in Adršpach in East Bohemia, a chateau in Mníšek pod Brdy and a former prison in Mlada Boleslav in Central Bohemia. Some of these buildings were as far as $200 \mathrm{~km}$ from Prague; others were heritage-protected buildings, which seriously complicated the implementation of construction works. Nevertheless, some changes were achieved, including the reconstruction of the purpose-built building of the original The Archive of the Land of Bohemia in the early 1980s, especially the strongroom for the deposition of the Archive of the Crown of Bohemia, containing the most important archivalia of the Czech state (1986, building of the new strongroom 1987-1990) ${ }^{2}$.

However, except for The Archive of the Land of Bohemia, no new archive buildings emerged for a long time after the end of World War II. The first exception was a building that was originally only a depository of the then Regional Archives of Hodonín (South Moravia). This was created in 19621964 by adapting the derelict machine house of the Hodonín Mills. In 1973-1976 it was expanded by a two-storey annexe with a raised ground floor containing a new depository and an office, workroom, toilet facilities and garage. The operation of this purpose-built archive building was ceremonially inaugurated on 6 October $1976^{3}$.

The other specialised archive building in the Czech Republic was built some years later in connection with the demolition of the ancient royal city of Most in North Bohemia, destroyed for the sake of opencast mining of brown coal. (This was simultaneously a political issue; a completely new town was built to replace the old one, and only the valuable Gothic Church of the Assumption of the Virgin Mary was, with the help of unique technology, moved in 1975 almost a kilometre to a new site). The new archive building in Most simultaneously solved previous problems of housing an archive that had

1. Rudolf KAĎOREK, Vznik a vývoj Státního ústredního archivu v Praze. In: Aby na nic a na nikoho nebylo zapomenuto. K jubileu ústředního archivu českého státu 1954-2004, Praha 2004, p. 30, 38.

2. Ibid., pp. 30-32.

3. See http://www.mza.cz/historie-3. 
found itself in what were, from the construction and technical aspects, inappropriate conditions. Construction was launched in September 1979, and the ceremonial opening took place in March $1984^{4}$.

While, at the beginning of the 1980s, the extensive modern building of what is today the Slovak National Archives in Bratislava was emerging in Slovakia, in the Czech part of what was at that time a federation, the previously mentioned purpose-built archive buildings remained an isolated example. In the 1970s and 1980s a new generation of archivists began to assert themselves in an effort to use experience from abroad and promote at least partial adaptations that would provide better conditions for work and storage, and in some cases more extensive adaptation and reconstruction of archive buildings ${ }^{5}$. Thanks to this, some of these buildings were maintained in a good condition and even saved. In the Czech Republic, it was the end of the 1980s before construction started on three more new archive buildings - in Karvina (1988) and Šumperk (1986) in North Moravia, and in Pelhřimov (1986-1989) in the Bohemian-Moravian Highlands. A fundamental change in development came about after 1989, thanks not only to the change in political conditions, even though this significantly contributed to the improvement in the situation of the archives. The political changes at the beginning of the 1990s brought not only the restitution of property injustices from the time of the totalitarian regime but also civic rehabilitation and reparations together with the privatisation of state and nationalised assets which increased the pressure on archives that had to be searched for the necessary archivalia, and the archivalia then put before the broad public. Archives thus imposed themselves much more strongly on the public consciousness, not as "warehouses of old paper", but as important memory institutes, essential for the functioning of society and the maintenance of the wealth of the archive for future generations. However, the changes mentioned often had a direct impact on the actual functioning of the archives - as a result of property restitution the archives began to lose the buildings belonging to monasteries and other church institutions, chateaux and various other buildings, and found themselves without a roof over their head. The State Central Archive was thus obliged to vacate its depositories in the Břevnov and Broumov monasteries; moreover, on the basis of legislative decisions, they were obliged to take over the archives of the former ruling political party (the Communist Party of Czechoslovakia) and its organs (for example, the special Institute of Marxism-Leninism) ${ }^{6}$, which represented another major demand on space and a further deterioration of the already critical situation concerning storage. A variety of possibilities (for example, carrying out extensive internal shredding, or building a record centre) were considered in the search for a solution, but it became plain that long-term the only effective and promising solution to the intolerable situation would be the construction of a new archive building ${ }^{7}$. Attempts first made in 1931 were thus revived to implement the construction of the building of the Archives of the Ministry of the Interior (one of the original components of the later Central State Archives), including a 1973 proposal for the construction of a Central Archives Complex, on the basis of which a preparatory study of intention to invest had been worked out in the mid1970s, but unfortunately in the end not realised. It was quite generous - as well as the Central State Archives it was to include the State Regional Archives in Prague and the Archives of the City of Prague (that was actually achieved in the end), as well as inter alia the Central Laboratory, the Central Archives School, and the Centre for the Vocational Retraining of Archive Employees at every level. Government Regulation no. 321 of 9 December 1987 became an important impulse for the fulfilment of at least some of these ideas. It charged the Interior Ministry with ensuring the preparation of draft documentation for the construction of a new building for the Central State Archives together with the State Regional Archives to be launched in 1990 to $1995^{\circ}$.

The climax of preparations for the construction of a new building for the Central State Archives, and especially the basic stimulus for the situation of other archives to be improved, was presented by Government Resolution of the Czech Republic no. 213 of 26 June 1991, for a complex analysis of the state of archive science in the Czech Republic". In it, the Czech government stated primarily that "ar-

4. Ivan VÍŠEK, Státni okresni archiv Most, http://litvinov.sator.eu/kategorie/krusnohori/statni-okresni-archiv-most.

5. Tomáš KALINA, K účelnosti adaptace historických objektů pro archivní účely. AČ 31, 1981, pp. 20-47; Id., Archivní budovy jako informační pracoviště. Zpravodaj pobočky ČSVTS při SÚA 32, 1987, pp. 1-93.

6. On the basis of Act No. 496/1990 Coll. concerning the return of property of the Communist Party of Czechoslovakia to the people of the Czech and Slovak Federative Republic (see http://www.zakonyprolidi.cz/cs/1990-496\#p1).

7. R. KAĎOREK, Vznik a vývoj Státního ústředního archivu v Praze, p. 32.

8. Ibid., pp. 32-34.

9. See http://racek.vlada.cz/usneseni/usneseni_webtest.nsf/0/3A590B159D1E98F4C12571B6006E0689. 
chive science in the Czech Republic has not previously received the attention it deserves with a view to its importance, and it has therefore found itself in a critical situation. The archives struggle with problems of storage space, personnel, and material and technical support. With regard to the unsuitable conditions in which the archives are kept, resulting from the state of both the buildings and the equipment in the depositories, and from the lack of storage space, the destruction up of 67,000 linear metres of archives and by 2000 of another 90,000, making up approximately half of the amount of archive documents in the Czech Republic, is actually threatened by 1995". A schedule of tasks aimed at remedying shortcomings in archive work was further approved and the competent ministers (above all the Minister of the Interior) were charged with ensuring that the tasks arising were fulfilled. They were first required immediately to look for the possibility of acquiring buildings on Czech territory and primarily in the area of the City of Prague (there in cooperation with the Mayor) suitable for the storage of archive materials, and subsequently, in the same year, to ensure (in cooperation with the Finance Minister) the setting aside of funds in the budget of the Interior Ministry of the Czech Republic for the construction of the already agreed archive complex in Prague, likewise the preparation of pre-project documentation for the construction of an archive building for what were then the State Regional Archives (today the Moravian Provincial Archives) in Brno. In addition, the Interior Minister was charged with "preparing a framework concept dealing with the premises and technical issues of archives in the Czech Republic" - and, furthermore, to upgrade the personnel of the Archives Administration Department of the Interior Ministry by a "review of existing nomenclature functions and salary scales of employees of the state archives and municipal and regional archives and within two years to draw up an amendment to the Act on Archives with a view to their qualifications and specialisations and to draft a proposal of principles for a new law ${ }^{10}$. Through this resolution the foundations were laid for an improvement of the situation of Czech archive science as a whole. In 1992 the Archives Administration submitted a report to the Czech government on the position of the regional archives. The outcome of this was a resolution of the government of the Czech Republic no. 385 of 27 May 1992, which stated that many of them "have for a number of years been unable to accept further archival acquisitions, which can lead to a real danger of damage to or destruction of archivalia; at the same time the archives' technical equipment lags behind development abroad". Simultaneously the Interior and Finance Ministries were charged with cooperation in dealing with construction for fourteen named district archives (including Olomouc, Tábor and České Budějovice), and the representatives of the cities of Prague, Brno, Ostrava, Pilsen and Ústí nad Labem were charged with "paying greater attention to tackling the storage and technical issues" of their own archives ${ }^{11}$. However, the Finance Ministry was very reluctant to allocate funding, so in the end the appropriate district authorities had to share in the construction of new buildings for the district archives ${ }^{12}$.

An important step in dealing with the question of archive storage came in early 1994 with the creation of the Commission for the Construction and Reconstruction of Archive Buildings under the Archives Administration Department of the Ministry of the Interior. This was charged on the one hand with compiling professional principles for purpose-built new buildings and the reconstruction of older buildings, on the other with monitoring the building activities of individual investors in archive buildings and providing them with methodological assistance and consultation. In the context of this Commission, methodological guidelines (typology of buildings) were worked out and issued independently for the State Regional Archives and the District Archives. This Commission was subsequently consulted on the majority of buildings undertaken and had a positive influence on their quality. Expert recommendations and information were also published in the $\operatorname{archive~journal~}^{13}$.

In subsequent years, it was possible to build first the building of the archive campus in Prague at Chodovec in particular. The ceremony of laying the foundation stone took place on 20 October 1992. The first two blocks for depositories were completed on 31 December 1994 and their trial op-

\footnotetext{
10. Ibid.

11. See http://racek.vlada.cz/usneseni/usneseni_webtest.nsf/0/C2D3687672D76D71C12571B6006BD724.

12. Vácslav BABIČKA, Předmluva, p. 7.

13. Vácslav BABIČKA, Předmluva. In: Bořivoj INDRA, Výstavba archivních budov v České republice 1990-2003, Praha 2004, pp. 5-8, there p. 7; Pavel GOŠ - Čeněk KADLEC - Bořivoj INDRA, Sborník typologických projektú - státní oblastni archivy. Praha 1993; Jiří VÍTU゚ - Bořivoj INDRA, Typologie budov - státni okresni archivy. Praha 1994; Bořivoj INDRA, Výstavba budov okresnich archivĩ. AC 44, 1994, pp. 151-155; Id., Klimatizace, ano či ne? AČ 45, 1995, pp. 50-53; Id., Archivni novostavby a problémy provoznich nákladi̊. AČ 52, 2002, pp. 1-17.
} 
eration inaugurated on 1 January 1995; the ceremonial opening took place on 7 April 1995. The transfer of almost $65 \mathrm{~km}$ of archive materials from the 13 buildings used at that time was launched straightaway on 3 January 1995 and continued until the end of 1998. A third depository block was completed in 1997 and eventually in 2001, after several years delay and after austerity measures, the operatively technical building whose ceremonial opening took place on 25 to 27 September $2001^{14}$. Construction of a new building for the Moravian Provincial Archives in Brno was to follow in connection with the completion of the archive complex in Prague at Chodovec. This had likewise been decided in 1991 and should have been completed in 1997, but because of the delay mentioned above, the solution to the issue of premises for the Moravian Provincial Archives was constantly postponed. It was not until 2003, partly in connection with the floods of 1997 and 2002, that the Interior Ministry decided to construct a purpose-built building for the Moravian Provincial Archives. This was confirmed by a sitting of the government in Brno on 12 May 2003. Land was purchased in 2004 and a preliminary project prepared, construction was launched in 2005 and completed two years later, and the ceremonial opening and commissioning took place on 27 October 2007. Thus the enormous efforts directed towards reliable security for more than $60 \mathrm{~km}$ of archive materials on the history of Moravia reached their culmination after many years of being moving around between various unsuitable workplaces and depositories.

Other archives were dealt with at the same time. Thanks to the above-mentioned governmental resolutions and especially their subsequent implementation, we entered a period sometimes called - in particular the years from 1991 to 2003 - the golden age of archive construction in the Czech Republic, or even the "Czech archival wonder", especially as far as the state archives are concerned. No wonder: during those years, 21 new archival buildings altogether were constructed (including three whose construction had been launched at the end of the 1980s and subsequently extended). Of these, the three biggest new buildings were conceived to serve jointly two state archives: the archives complex at Chodovec in Prague for the National Archives and the State Regional Archives in Prague, and buildings in Olomouc and České Budějovice for the relevant State District Archives and additionally for some workplaces of the State Regional Archives in Třebon and the Provincial Archives in Opava. We have to add reconstructions and adaptations to these, in some cases annexes; eight historically valuable buildings, among them castles, chateaux and dissolved monasteries, were preserved for archival purposes through rebuilding; in 29 cases extensive adaptations of buildings built originally for other purposes were carried out; and eleven such reconstructed earlier buildings acquired additions of completely new buildings for depositaries ${ }^{15}$. Thus out of 80 state archives and five statutory municipalities with independent archives, 58 - that is, $72.5 \%$ - acquired suitable conditions for the permanent storage of archive materials. Conditions for storing archive materials were substantially improved even in the remaining archives ${ }^{16}$. Of the most important new buildings, we can mention those of the state district archives in Benešov, Beroun, Př́bram and Rakovník in Central Bohemia; České Budějovice, Česky Krumlov and Strakonice in South Bohemia; Plasy in West Bohemia; Česká Lípa and Semily in North Bohemia; Chrudim in East Bohemia; and Kroměříž, Přerov and Frýdek-Místek in North Mora$\mathrm{via}^{17}$. Quite apart from the potential financial savings, many of these buildings are interesting from the

\footnotetext{
14. R. KAĎOREK, Vznik a vývoj Státniho ústředního archivu v Praze, p. 34; Ludmila VLAŠANÁ, Archivni areál v Praze 4-Chodovci. Současný stav a perspektivy. AČ 45, 1995, p. 205-220; Bořivoj INDRA, Neue Archivgebäude in der Tschechischen Republik (Archivni areál Praha). In: Der Archivar. Mitteilungsblatt für deutsches Archivwesen 47, 1994, 4, p. 355357; Id., Der Neubau der staatlichen Archive in Prag. In: Archivalische Zeitschrift 84, 2001, p. 175-204; Tomáš KALINA, Novostavba Státního ústredního archivu a Státního oblastního archivu v Praze-Chodovci. In: Státní ústřední archiv v Praze a jeho sídla. Praha 2001, pp. 23-39.

15. For an evaluation of experience with the construction of new buildings, the adaptation of older ones and the reconstruction of historical buildings or constructions and the reconstruction of depositories, see Bořivoj INDRA, Výstavba archivnich budov $v \check{C} R$ 1990-2003. Praha 2004, pp. 39-48.

16. B. INDRA, Výstavba archivnich budov v ČR 1990-2003, pp. 37-38.

17. An overview of all the buildings is given in Popisy jednotlivých staveb a rekonstrukcí státních a mèstských archivi uskutečnèných v letech 1990-2003. In: B. INDRA, Výstavba archivnich budov v ČR 1990-2003, Praha 2004, pp. 77-198. On some buildings at least Věra MAŠKOVÁ, Nová budova státniho okresního archivu v Českém Krumlovè. AC 45, 1995, p. 245; Vlastimil KOLDA, Státni okresni archiv České Budějovice, obrazový soubork otevřeni nové budovy. České Budějovice 1996; Petr HAVLOVIČ, Státni okresni archiv Klatovy v nové účelové budovè. AČ 47, 1997, p. 98; Dáša SEBEROVÁ, Výstavba a rekonstrukce archivních budov státnich okresnich archivĩ na severni Moravé a ve Slezsku (Státni okresni archivy Frýdek-Mistek, Jeseník, Karviná, Olomouc, Přerov, Šumperk, Vsetín). AČ 47, 1997, pp. 19-22; Bořivoj INDRA, Nový okresní archiv v Př́brami - komplexni réseneni. AČ 47, 1997, pp. 95-96; Id., Státni okresní archiv Mladá Boleslav - jiné résení. AČ 48, 1998, pp. 37-39; Id., Nová budova Státního okresního archivuv Benešově. AČ 50, 2000, pp. 223-226; Jana BLAŽKOVÁ,
} 
architectural point of view ${ }^{18}$. This success culminated with the inauguration of the building for the Moravian Provincial Archives in Brno in 2007, up to now the most modern archive building in the Czech Republic. The new and reconstructed buildings not only helped to solve the shortage of storage space, but above all radically changed the conditions for conservation. The approach to their construction took into consideration modern requirements for the care of archive materials and at the same time changes were made to what were often undignified working environments for the work of the archivists. Paradoxically, the fact that Czech archive science had previously lagged behind became an advantage, because it was possible to gain inspiration from abroad where modern archive buildings had been under construction since the 1970s, and to take cognisance not only of positive experiences but also of what had not passed the test ${ }^{19}$. No other country recorded such a high number of newly built or reconstructed archival buildings in such a short time as the Czech Republic after 1990. Many circumstances contributed to this successful outcome; not only the political changes but also the favourable social climate, substantially supported by the archives themselves through their tireless service to the public. The essential necessity of dealing with preceding unsatisfactory care and neglect, and even the delayed care in the housing of the archives and conservation of archivalia also played their role. The immediate clarity of the aims and requirements of the archivists, and their art of convincing the appropriate state authorities of the need to construct or reconstruct archive buildings was also important. From this point of view, competitiveness and rivalry among representatives of the district authorities (the lower levels of the state administration) responsible for the district archives was also valuable.

However, this ideal situation lasted only until 2003. With regard to the aforementioned attachment of the district archives to the district authorities, the abolition of the district authorities in the Czech Republic - which took place in 2002 in connection with the reform of public administration brought about a major new change, to which was added the passage of the district archives to the state regional archives (under the Archives Act of 2004) - that is, they came directly under the Ministry of the Interior - and on top of that a reduced budget and increased expenses. After the decline of the Czech economy in 2008, following the worldwide economic crisis and the increase of various austerity measures, the situation for Czech archives again became more complicated.

Despite this, several more modifications were successfully carried out in recent years, notably of those state archives, especially regional, which it had not yet been possible to take care of and where the ongoing situation had to be dealt with. In recent years former warehouses for medicaments and a reserve hospital in Klášter near Nepomuk in West Bohemia were reconstructed as a workplace for the State Regional Archives in Pilsen, and the State Regional Archives in Litoměřice had to acquire premises for archive materials it needed to move out of a former depository in a local chateau. The depository in Děčín also underwent modification. The adaptation of a former Augustinian monastery in Třeboň was completed last year, providing storage for the local State Regional Archives, which were thus relocated after centuries. Nevertheless, there are some State Regional Archives that still need to acquire a completely new building (Louny, Karlovy Vary, Sokolov).

After 1990, the premises of some non-governmental archives could also be improved. These included above all the Archives of the City of Prague that were likewise housed in unsuitable conditions, especially after the neo-Gothic wing of the Prague Old Town Hall in which they were housed was burnt down in May 1945. There had been suggestions and deliberations about constructing new

Českolipský archiv má účelovou novostavbu. AČ 50, 2000, pp. 37-40; Marie BISINGEROVÁ et alii, Státní okresni archiv Kutná Hora. Kutná Hora 2001; Emil KORDIOVSKÝ et alii, Státní okresní archiv Břeclav se sídlem v Mikulově. Mikulov 2001; and others.

18. E.g. Vladimír CZUMALO, Archiv mezi typem, mistem, jazykem a krásou (Státní okresni archiv Semily). In: Z Českého ráje a Podkrkonoší: vlastivědný sborník 9, 1996; Architekt 24, 1995. The architectural solutions for archive buildings in Semily and in Strakonice won the award of the Community of Architects of the Czech Republic; in the context of the world fair FOR ARCH 1995, the depositories building for the state archives in the archive complex in Prague-Chodovec was awarded honorary mention and the title "Building of the Year 1995"; the title "Building of the Year 1996" was awarded to the town of Uherské Hradiště for their reconstruction of the former Franciscan Monastery for the State Regional Archives - see B. INDRA, Výstavba archivnich budov v ČR 1990-2003, pp. 10, 42.

19. Vácslav BABIČKA, Predmluva, p. 8. Czech archivists took as their starting point primarily the works Batiments d'archives, vingt ans d'architecture francaise 1965-1985. Paris 1986, and Christopher KITCHING, Archive Buildings in the United Kingdom 1977-1992. London 1993; Michel DUCHEIN - Peter WALNE, Archive Buildings and Equipment. München 1988. 
buildings straight after the end of the war, and again in the early 1960s. However, these were not realised largely owing to financial reasons. A decisive stimulus came with a resolution by Prague City Council on 16 April 1992 to start preparing for investment in a new purpose-built building for the Archives of the City of Prague and, definitively, with a resolution of March 1994 deciding about its actual realisation. A plot of land was selected at Chodovec in Prague in the vicinity of the Central State Archives and State Regional Archives in Prague, by that time already built. In this way a unique and architecturally interesting archive complex emerged in that area, offering a complex service for archivalia and those interested in studying them. It is moreover possible to store around $280 \mathrm{~km}$ of archival materials, i.e., maybe $40 \%$ of the archival resources of the Czech Republic ${ }^{20}$. In addition, reserved land for another building exists alongside the completed depot. The premises of the Archives of the City of Brno and the Archives of the City of Ostrava were also renovated or expanded. Various specialised archives are likewise gradually undergoing modernisation, archives for which the technical parameters for construction are directly prescribed in the Act on Archives and File Service No. 499/2004 Coll. as a condition of being awarded accreditation by the Ministry (archives, frequently traditional and with a rich past, that were already in existence when the Act was passed were granted an exception and a period within which this condition could be fulfilled) - and they often represent a tool for the founder of these archives, in the allocation of appropriate funding. In recent years, for example, modifications were made in this way to the Archives of the National Museum and the Archives of the Charles University, for which the construction of a new building is also under consideration.

In the construction of new buildings and adaptation or reconstruction of older buildings it was possible to devote thorough attention to very varied questions - beginning with the actual location of the archives and the concept of the buildings, through to the shape and equipment of the depositories, the restoration workshop and the photo laboratory, as well as further premises intended for archivists and for the use of archivalia, that is, for the public. Experiences with dealing with fire protection measures and technical construction issues were valuable, the reconstruction of protected heritage and historic buildings in particular requiring a specific approach ${ }^{21}$.

In the last twenty years, Czech archives have thus acquired a great many new buildings that fulfil modern requirements for the preservation of, and access to, archive materials. This does not of course mean that the battle is permanently won and that the present situation is absolutely perfect. With the passing of time the real value of the archive buildings is gradually depreciating while operational expenses, especially on energy and services, are continually increasing, and in the light of the economic situation, resources will in some cases be insufficient. Adequate long-term funds are lacking for the acquisition and renovation of movable and immovable assets, including shelves; for the equipping of restoration workshops and research rooms (computers for looking at digital copies of archive materials, reading machines); for the support of documentation services, the ensuring of security and CCTV systems, air conditioning and ventilation, HVAC measuring and regulation of the climate in the depositories, not to mention the maintenance of electrical and plumbing installations, boilers, etc. Some equipment especially is aging, and will have to be replaced when its lifetime comes to an end providing that the threat to both the buildings themselves and to their equipment, and above all the archive materials kept in them, does not get worse. Although the situation is not critical at the present time, the equipment in most of the state archives requires, and will continue to require, gradual replacement. Almost every archive of the State Archives under the Archives Administration of the Ministry of the Interior is facing the question of how to deal with these problems.

At the same time, where some things are concerned new methods of obtaining funding are being sought - various projects are emerging, above all in the field of digitalisation of archives, and various institutions and organisations are cooperating with each other. In this respect, important projects include Manuscriptorium (aimed at making manuscripts accessible, in cooperation with the National Library of the Czech Republic); Monasterium (a virtual archive of medieval and Early Modern Period

20. See http://www.ahmp.cz/index.html?mid=9\&wstyle=0\&page=page/docs/budova-Chodovec.html; B. INDRA, Výstavba archivnich budov $v$ CRR 1990-2003, p. 10.

21. B. INDRA, Výstavba archivních budov v ČR 1990-2003, p. 37-68, esp. pp. 46-68, also Plány novostaveb některých vybraných archivních budov, pp. $71-76$ (Archiv campus, Beroun, Frýdek-Místek, Olomouc, Př́bram, Semily). A summary of experience in using new and adapted buildings with some years delay is provided by Ead., Archivni budovy a perspektivy jejich výstavby. Praha 2008 (English Summary pp. 7-8). 
documents of Central Europe of primarily ecclesiastical provenance - a project managed by the organisation ICARUS); Porta fontium (on which Western Bohemian and Bavarian archives are cooperating); SOA Zámrsk in East Bohemia is cooperating with the University of Hradec Králové in the provision of archive digitalisation; and the Provincial Archives in Opava digitalised large-scale maps and plans in cooperation with the National Heritage Institute. Several archives (SOA Třeboň, SOA Litomerrice, ZA Opava) are cooperating with the Genealogical Society of Salt Lake City in Utah on the digitalisation of matrices, requested especially by the research community. It will be necessary to continue in these activities too, and to search for similar solutions in the future.

Despite the above-mentioned problems, the position of the State Archives in the Czech Republic remains relatively satisfactory. The obsolescence of buildings and their equipment has not yet reached a critical state - quarter of a century ago Czech archivists could only have dreamed of being in a similar position. However, the responsibility for looking after the archival wealth and its future development will bring additional demands in this field and require solutions.

\section{SUMMARY}

Ideas about modern, well-lit buildings built to suit specific needs and requirements were implemented only gradually. It was much the same in the Czech Lands, where the first purpose-built archival building was put up between 1929 and 1933 for The Archive of the Land of Bohemia. For a long time this building remained the only one of its kind. Except for The Archive of the Land of Bohemia, no new archive buildings emerged for a long time after the end of World War II. the first exception was a building that was originally only a depository and then office of the then Regional Archives of Hodonín (South Moravia, 1962-1964 and 1973-1976), the second the new archive building in Most (North Bohemia, 1979-1984). In the 1970s and 1980s a new generation of archivists began to assert themselves in an effort to use experience from abroad and promote at least partial adaptations that would provide better conditions for work and storage, and in some cases more extensive adaptation and reconstruction of archive buildings. In the Czech Republic, it was the end of the 1980s before construction started on three more new archive buildings - in Karviná (1988) and Šumperk (1986) in North Moravia, and in Pelhřimov (1986-1989) in the Bohemian-Moravian Highlands. A fundamental change in development came about after 1989, thanks not only to the change in political conditions, even though this significantly contributed to the improvement in the situation of the archives. The basic stimulus for the situation of the archives to be improved, was presented by Government Resolution of the Czech Republic no. 213 of 26 June 1991, for a complex analysis of the state of archive science in the Czech Republic, and a resolution of the government of the Czech Republic no. 385 of 27 May 1992. Thanks these resolutions and especially their subsequent implementation, we entered a period sometimes called - in particular the years from 1991 to 2003 - the golden age of archive construction in the Czech Republic, or even the "Czech archival wonder", especially as far as the state archives are concerned. During those years, 21 new archival buildings altogether were constructed, 8 historically valuable buildings were preserved for archival purposes through rebuilding; in 29 cases extensive adaptations of buildings built originally for other purposes were carried out; and 11 such reconstructed earlier buildings acquired additions of completely new buildings for depositaries. Thus out of 80 state archives and five statutory municipalities with independent archives, 58 - that is, $72.5 \%$ - acquired suitable conditions for the permanent storage of archive materials. Conditions for storing archive materials were substantially improved even in the remaining archives. No other country recorded such a high number of newly built or reconstructed archival buildings in such a short time as the Czech Republic after 1990. After 1990, the premises of some nongovernmental archives could also be improved, these included above all the Archives of the City of Prague. In the last twenty years, Czech archives have thus acquired a great many new buildings that fulfil modern requirements for the preservation of, and access to, archive materials. This does not of course mean that the battle is permanently won and that the present situation is absolutely perfect. With the passing of time the real value of the archive buildings is gradually depreciating while operational expenses, especially on energy and services, are continually increasing, and in the light of the economic situation, resources will in some cases be insufficient. The position of the State Archives in the Czech Republic remains relatively satisfactory. However, the responsibility for looking after the archival wealth and its future development will bring additional demands in this field and require solutions.

Typology: 1.04 Professional Article

Submitting date: 15.03 .2015

Acceptance date: 09.04.2015 